\title{
Pseudo-Myasthenia Gravis and Thymic Hyperplasia in Graves' Disease
}

\author{
Michael W. Nicolle
}

\begin{abstract}
Background: Diagnostic confusion between thyroid disease and myasthenia gravis (MG) can arise because the two may have similar clinical features, and also because of the more frequent coexistence of these autoimmune disorders in the same individual. In MG, autoantibodies directed against the acetylcholine receptor result in muscle weakness. Thymic pathology is well recognized in MG, with thymic hyperplasia frequent in early onset MG and thymoma more common in later onset MG. In Graves' disease, autoantibodies against thyroid antigens result in hyperthyroidism. A seldom-recognized feature of Grave's disease is the occurrence of an enlarged thymus (thymic hyperplasia) on chest CT, or of thymic lymphoid hyperplasia pathologically. Case study: This report describes a case in which the discovery of a mediastinal mass during imaging of the thyroid, and the presence of myasthenic-like symptoms, in a patient with Graves' disease prompted investigations into whether the patient also had MG. Results: Despite symptoms which strongly suggested MG, subsequent investigations did not confirm the diagnosis, and treatment of Grave's lead to a resolution of the symptoms and regression of the thymic enlargement seen on CT. Conclusions: The case study highlighted clinical similarities between Grave's disease and myasthenia gravis which might cause diagnostic confusion, and also the investigations which are useful in order to differentiate the two diseases. In addition to common clinical features, the autoimmune diseases Grave's disease and myasthenia gravis may both produce radiological thymic enlargement.
\end{abstract}

RÉSUMÉ: Pseudo-myasthénie grave et hyperplasie du thymus dans la maladie de Graves. Introduction: Il peut exister de la confusion entre la maladie thyroïdienne et la myasthénie grave (MG) quant au diagnostic parce que les deux entités peuvent avoir des caractéristiques cliniques similaires et également à cause de la coexistence plus fréquente de ces deux maladies auto-immunes chez le même patient. Dans la MG, des auto-anticorps dirigés contre les récepteurs de l'acétylcholine induisent une faiblesse musculaire. La pathologie thymique est bien reconnue dans la MG, les patients présentant fréquemment une hyperplasie du thymus dans la MG à début précoce et le thymome est plus fréquent chez les cas à début tardif. Dans la maladie de Graves, les autoanticorps dirigés contre des antigènes thyrö̈diens induisent une hyperthyroïdie. Une manifestation de la maladie de Graves qui est rarement reconnue est la présence d'un thymus augmenté de volume (hyperplasie thymique) au CT du thorax ou d'une hyperplasie lymphoïde thymique à l'anatomopathologie. Étude de cas: Nous rapportons le cas d'un patient atteint de la maladie de Graves chez qui la découverte d'une masse médiastinale à l'imagerie de la thyroìde et la présence de symptômes ressemblant à la myasthénie ont motivé l'investigation de la possibilité que le patient ait également une MG. Résultats: En dépit de symptômes suggérant fortement la présence d'une MG, l'investigation n'a pas confirmé ce diagnostic et le traitement de la maladie de Graves a induit une résolution des symptômes et la régression de l'hypertrophie du thymus a été démontrée par CT scan. Conclusions: Cette étude de cas souligne les similitudes cliniques entre la maladie de Graves et la myasthénie grave, ce qui peut provoquer de la confusion quant au diagnostic, et indique également les investigations qui sont utiles pour différencier les deux maladies. En plus d'avoir des caractéristiques cliniques communes, ces deux maladies auto-immunes peuvent toutes deux donner des images radiologiques d'augmentation de volume du thymus.

Can. J. Neurol. Sci. 1999; 26: 201-203

Thymic involvement likely occurs to varying degrees in several autoimmune diseases.' In myasthenia gravis (MG), approximately $65 \%$ of early onset MG patients have pathological evidence of thymic lymphoid hyperplasia, with germinal center formation, while $15 \%$ of all MG patients have a neoplastic thymoma, more common in later onset MG. ${ }^{2}$ Thymectomy is generally recommended in the management of such MG patients. ${ }^{3}$ The scientific rationale supporting this is the finding that $\mathrm{T}$ lymphocytes isolated from the MG hyperplastic thymus proliferate in response to the acetylcholine receptor (AChR), the target autoantigen in MG, and that the hyperplastic thymus is enriched in B lymphocytes producing anti-AChR antibodies. ${ }^{2}$ Because of the well-recognized association between $M G$ and thymic abnormalities, the finding of a thymic mass often prompts investigations looking for evidence of MG. This report describes a case in which the finding of a mediastinal mass at the time of thyroid imaging in a young woman with Graves' disease led to the suspicion that MG might explain some of the clinical symptoms. Multiple investigations failed to substantiate this. Instead, it appeared that the mediastinal "mass", which resolved with medical therapy, was likely thymic hyperplasia secondary to Graves' disease alone. This case emphasizes the fact that the thymus is involved in diseases other than MG, that the clinical features of

From the Department of Clinical Neurological Sciences, University of Western Ontario, London Health Sciences Centre, 339 Windermere Road, London, Ontario, Canada N6A 5A5

RECEIVED OCTOBER 13,1998. ACCEPTED IN FINAL FORM MARCH 6, 1999.

Reprint requesis to: Michael W. Nicolle, Director, Myasthenia Gravis Clinic, Department of Clinical Neurological Sciences, University of Western Ontario, London Health Sciences Centre, 339 Windermere Road, London, Ontario, Canada N6A 5A5 
Graves' may overlap with those of MG, and that other diagnostic methods may be needed to differentiate between the two.

\section{Case Report}

\section{Clinical}

A 35-year-old previously healthy woman presented with weight loss, a sore throat, a rapid heart rate, and drooping of the left eye lid. Systemic review revealed general fatigue, anxiety, insomnia and blurring of vision without diplopia. There was a strong family history of autoimmunity; her mother with early-onset diabetes, one sister with thyroid carcinoma, another with both Addison's disease and Graves' disease, and several first cousins with hypothyroidism, diabetes or vitiligo.

Examination by the endocrinologist showed her to be anxious, with a resting heart rate of $90 \mathrm{bpm}$. There was a palpable right thyroid nodule without generalized thyroid enlargement. There was right sided lid retraction, and globe and lid lag with questionable non-fatigable ptosis on the left. A neurological assessment revealed the additional symptoms of worsening in the left-sided ptosis in the evening, a hoarse voice, dyspnea with exertion and mild swallowing difficulties, attributed largely to neck pain. The examination showed her to be thin and anxious. There was lid retraction and lid lag on the right, questionably fatigable ptosis on the left, and mild non-fatigable weakness of eye closure, neck flexion and of the proximal arms and legs. The remainder of the neurologic examination was normal.

\section{Investigations}

Initial thyroid function tests showed an elevated free $\mathrm{T} 4$ at $26 \mathrm{pmol} / \mathrm{L}$ (normal $<21 \mathrm{pmol} / \mathrm{L}$ ), and a suppressed TSH $(<0.05 \mathrm{mIU} / \mathrm{L}$ ). An aspirate of one of the nodules revealed sparse thyroid cells without malignancy. Iodine ${ }^{131}$ uptake was diffusely and homogeneously increased without focal cold areas. A thyroid ultrasound showed three hypoechoic nodules. A CT of the neck and upper mediastinum showed the thyroid nodules, consistent with a multinodular goitre, but in addition showed a $4 \times 1.5 \mathrm{~cm}$ anterior mediastinal mass, raising concerns that this may be a thymoma (Figure A). A CT of the orbits was normal, without enlargement of the extraocular muscles.

After the neurological assessment, several other investigations were performed. A blinded tensilon test showed no improvement in her ptosis. Repetitive nerve stimulation (RNS) at $3 \mathrm{~Hz}$ of the facial, accessory and phrenic nerves with recording from nasalis, trapezius and diaphragm respectively, was normal without decrement. Single fiber EMG (SFEMG) of the left orbicularis oculi muscle was also normal, without jitter or blocking in the 18 fiber pairs isolated. Anti-AChR antibodies were negative on two separate occasions.

\section{Course}

She was treated initially with propranolol $(80 \mathrm{mg}$ po bid) and methimazole (15 mg po bid) with some improvement in her symptoms. One month later, after neurologic assessment and prior to the results of investigations, mestinon $60 \mathrm{mg}$ po gid was started without improvement. Three weeks later prednisone $20 \mathrm{mg}$ po od was added. She slowly improved over the next month. Repeat thyroid function studies three months later showed a normalization of the TSH and free T4 levels. After the completion of investigations, the prednisone was tapered and discontinued. A follow up CT scan done 5 months after the first demonstrated a dramatic reduction in the size of the thymus (Figure B). Two years later she does well on methimazole only.

\section{Discussion}

The diagnosis of Graves' disease in this woman is secure, as shown by the clinical picture, elevated free $\mathrm{T} 4$ and suppressed TSH. The history of generalized weakness, fluctuating ptosis with worsening towards the end of the day, dysphonia, dyspnea and dysphagia all correctly suggested that she might also have MG. However, multiple investigations failed to support this. Although not specific for MG, a positive tensilon test is sensitive for the presence of a defect in neuromuscular transmission,
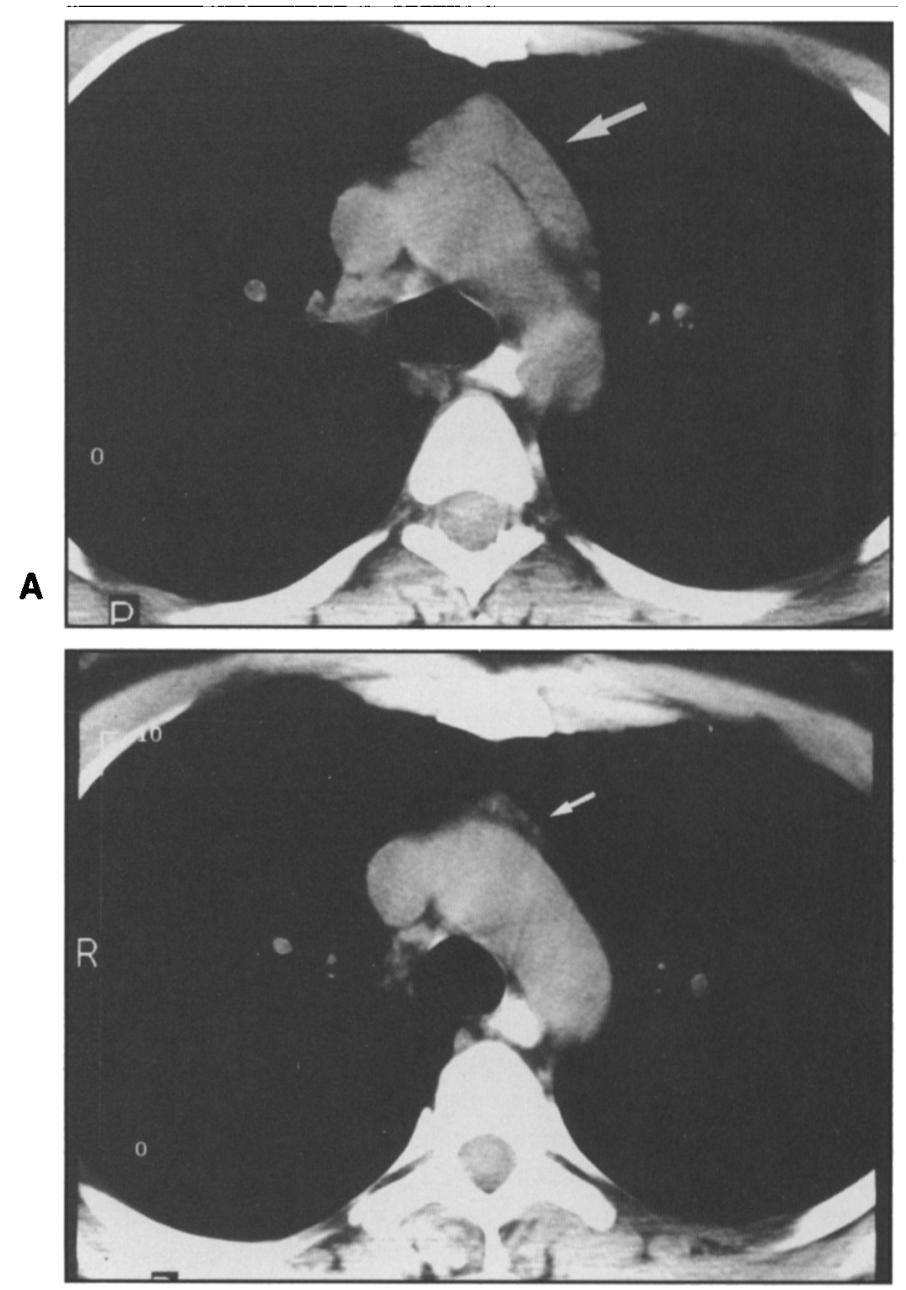

B

Figure: $A) C T$ of the chest before treatment showing the anterior mediastinal enlargement (large arrow). B) CT of the chest after medical treatment demonstrating a marked reduction in the size of the anterior mediastinal enlargement (small arrow).

and is positive in $80-90 \%$ of individuals with MG. ${ }^{4}$ Repetitive nerve stimulation produces abnormal decrement in $70-80 \%$ of individuals with purely ocular MG, and $80-90 \%$ of individuals with more generalized weakness. ${ }^{5}$ SFEMG is even more sensitive, with $95 \%$ or more of individuals showing jitter in clinically weak muscles. ${ }^{6}$ Finally, anti-acetylcholine receptor antibodies, elevated in $85-90 \%$ of individuals with generalized $\mathrm{MG}^{7}{ }^{7}$ were not detectable. Although negative results in any one of these studies does not exclude the diagnosis, the fact that all were negative and that she continues to improve with medical treatment of her thyroid disease alone makes the diagnosis of MG highly unlikely. In this case, the presence of an enlarged thymus also suggested the presence of MG. Although initially thought to represent a thymoma, as the vast majority if not all of MG patients with thymoma are seropositive for anti-AChR antibodies, ${ }^{8}$ the absent anti-AChR antibodies prompted a review of the CT scan and a re-interpretation that the mass, represented thymic hyperplasia. With medical therapy the thymic enlargement gradually resolved (Figure B), as has been noted in Graves' by others. ${ }^{1}$

The role of the thymus in other autoimmune disorders is less 
well studied than in MG. Thymic hyperplasia is not infrequently seen in Graves', either macroscopically on CT, ${ }^{1,9-13}$ or microscopically ${ }^{9,14}$ Thyrotropin receptors, the target of some autoantibodies in Graves', have been detected in thymic tissue. ${ }^{1}$ Just as the presence of the AChR in thymic myoid or epithelial cells is thought to be involved in the pathogenesis of $\mathrm{MG}^{2}$ perhaps the presence of the thyrotropin receptor in thymic epithelial cells may also be involved in the pathogenesis of Graves' disease.' Conversely, in one study immunoglobulins from a patient with Graves' disease and thymic hyperplasia promoted thymocyte mitogenesis, suggesting that thymic hyperplasia may be a consequence, and not a cause, of Graves' disease. ${ }^{9}$ Elevated levels of thyroid hormones may also promote thymic hyperplasia, perhaps accounting for the radiographic evidence of resolution of thymic hyperplasia with medical treatment of her hyperthyroidism. ${ }^{\prime}$ Although there may be scientific rationale for thymectomy in Graves', the availability of effective medical therapies, and the ability to ablate the single target organ involved, negates the need for such an aggressive therapy in Graves' disease.

Thus the clinical features of MG and Graves' may be similar, and thymic hyperplasia may occur in both. This needs to be taken into account, and the appropriate investigations undertaken when considering the diagnosis of myasthenia in a patient with hyperthyroidism.

\section{REFERENCES}

1. Murakami M, Hosoi Y, Negishi T, et al. Thymic hyperplasia in patients with Graves' disease. Identification of thyrotropin receptors in human thymus. J Clin Invest 1996; 98: 2228-2234.
2. Hohlfeld R, Wekerle $\mathrm{H}$. The thymus in myasthenia gravis. Neurol Clin 1994; 12: 331-342.

3. Lanska DJ. Indications for thymectomy in myasthenia gravis. Neurology 1990; 40: 1828-1829.

4. Weinberg DA, Lesser RL, Vollmer TL. Ocular myasthenia: a protean disorder. Surv Ophth 1994; 39: 169-210.

5. Gilchrist JM, Massey JM, Sanders DB. Single fibre EMG and repetitive stimulation of the same muscle in myasthenia gravis. Muscle Nerve 1994; 17: 171-175.

6. Oh SJ, Kin DE, Kuruoglu R, Bradley RJ, Dwyer D. Diagnostic sensitivity of the laboratory tests in myasthenia gravis. MuscleNerve 1992; 15: 720-724.

7. Vincent $\mathbf{A}$, Newsom-Davis $\mathbf{J}$. Acetylcholine receptor antibody as a diagnostic test for mayasthenia gravis: results in 153 validated cases and 2967 diagnostic assays. J Neurol Neurosurg Psychiatry 1985; 48: 1246-1252.

8. Beekman R, Kuks JBM, Oosterhuis HJGH. Myasthenia gravis: diagnosis and follow-up of 100 consecutive patients. J Neurol 1997; 244: 112-118.

9. Wortsman J, McConnachie P, Baker JR, Burman KD. Immunoglobulins that cause thymocyte proliferation from a patient with Graves' disease and an enlarged thymus. Am J Med 1988; 85: 117-121.

10. Bergman TA, Mariash CN, Oppenheimer JH. Anterior mediastinal mass in a patient with Graves' disease. J Clin Endocrinol Metab 1982; 55: 587-588.

11. Ford HC, Savage T, Delahunt JW. Anterior mediastinal mass and Graves' disease. Thorax 1985; 40: 469-470.

12. Allard JC, Lee VW, Franklin P. Thyroid uptake of gallium in Grave's disease. Clin Nucl Med 1988; 13: 663-666.

13. Wolfe LK. Myasthenia gravis and Graves' disease. South Med J 1988; 81: 1334-1335.

14. Fyfe B, Dominguez F, Poppiti RJ Jr. Thymic hyperplasia. A clue to the diagnosis of hyperthyroidism. Am J Forensic Med Pathol 1990; 11: 257-260. 